MAGDALENA ŁANUSZKA

Kraków, Międzynarodowe Centrum Kultury

\title{
Late Gothic Panels from the Collection of York Art Gallery: Predella-Wings from the Workshop of Hans Pleydenwurff
}

$\mathrm{T}$ he following article is a result of the research on continental European paintings in York Art Gallery, completed as a part of the project National Inventory of Conti nental European Paintings. ${ }^{1}$ Two late gothic panels, painted on both sides, were given to the York Art Gallery in 1957 by F.D. Lycett Green. They have been described as by Nuremberg School and dated back to the second half of the fifteenth century. The known provenance goes back to the collection of Louis Breitmeyer, whose sale at Christie's, Manson \& Woods in London on $27^{\text {th }}$ June 1930 included the panels. They were later sold at an anonymous sale again at Christie's, Manson \& Woods in London on $15^{\text {th }}$ July 1955 (lot 108), as by Master of Liesborn. In 1956 the panels were with the Arcade Gallery in London, from where they were purchased by F.D. Lycett Green in 1957 and given by him to the Art Gallery in York through the National Art Collections Fund. ${ }^{2}$

\footnotetext{
${ }^{1}$ The project was created in 2001 to provide the research on pre-1900 Continental European oil paintings in various English collections, as a partnership between the History of Art departments at Birkbeck, University of London, University of Glasgow, and the National Gallery in London. The results of the research are added to the online resource 'NICE Paintings': the National Inventory of Continental European Paintings, which is published by the Visual Arts Data Service (http://www.vads.ac.uk/collections/NIRP/index.php). Initial funding for the project was provided by the National Gallery; substantial grants have been received from the Arts and Humanities Research Council, the Getty Foundation and the Kress Foundation. Additional research has been carried out through the Neil MacGregor Scholarships funded by the National Gallery Trust and by Pilgrim Trust research grants awarded to selected museums. I would like to thank Mr Andrew Greg, the Director of the project, and Ms Jennifer Alexander, the Curator of the York Art Gallery, for their kind support for my work. I would like to thank Mr Richard Green for his valuable comments and research advice both during my stay in York and while preparing this article.

2 York Art Gallery Catalogue - Catalogue of Paintings, vol. I: Foreign Schools 1350-1800, City of York Art Gallery, York 1961, pp. 89-90. Francis Dennis Lycett Green (known to family and friends as Peter, 1893-1959) was a member of wealthy industrial Green family from Wakefield that was among the great philanthropic benefactors of York. He began buying pictures during the 1920s, advised by some of the most famous art dealers of the day. By the 1940s, he owned examples from almost every school and period of European Art - a comprehensive collection of over 130 paintings dating back from early fourteenth century to the end of the eighteenth century, representing every important European school of art. In 1952, he offered it to the National Gallery of South Africa, having moved to Cape Town in the hope that the climate would improve his health (which was poor because he was badly injured in the First World War). However, when a dispute arose with the Cape Town Gallery, Francis withdrew his pictures in protest and shipped them back to England. The entire collection of 130 pictures was at first on loan to the York Art Gallery and in the Spring of 1955 he decided to give it to the Gallery. Two late gothic German panels were additionally given by him two years later.
} 

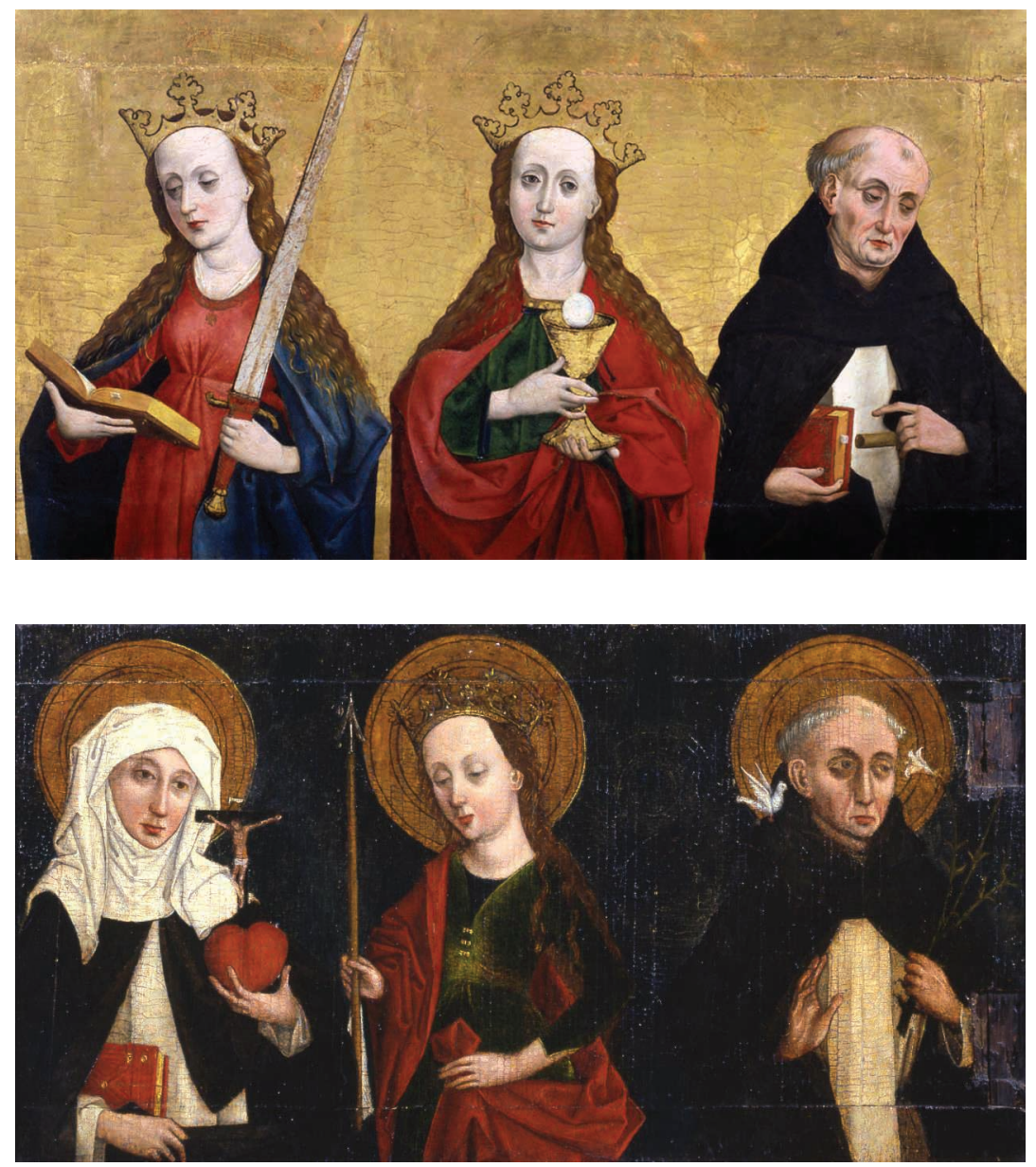

1. Panel YORAG 898b: recto and verso sides; York Art Gallery

Both panels were painted on pine-wood, both measuring $25 \times 49.1 \mathrm{~cm}$. They contain the depictions of three saints in half-length on each side. One side of each panel has a golden background, suggesting it used to be in the inner side of the altar-wings, while at the other side the saints are placed against the dark background (outer side of the altar-wings). Unfortunately, nowadays only one of these panels is still in York Art Gallery (number 898 b, Fig. 1), as the other one (898a, Fig. 2) was stolen from the Gallery on $13^{\text {th }}$ November 1979 and its current location remains unknown.

In the recto side of the panel still present in York Art Gallery, one male and two female saints are depicted against the golden background. All three figures previously had halos around their heads, evidenced by double-lined circles painted probably in black line on the golden background; the remains of those lines are now barely visible. The crowned lady to the right (holding a book and a sword) is most likely St Catherine of Alexandria, although the artist did not include her most popular attribute: the broken wheel. The saint is reading from the book she holds, turning slightly left; she is wearing a red dress and a blue cloak. In the middle of the panel another crowned lady is depicted looking straight at the viewer; she is wearing a green dress and a red cloak and holds a chalice with the wafer, which identifies her as St Barbara. The only male saint here is depicted to the right edge of the panel, also turned slightly right and looking down; he is a monk holding a book and possibly a Tau-cross-shaped staff, which is usually understood as an attribute of St Anthony the Hermit. He is an old man, but clean shaved and tonsured; he is wearing a white habit and 

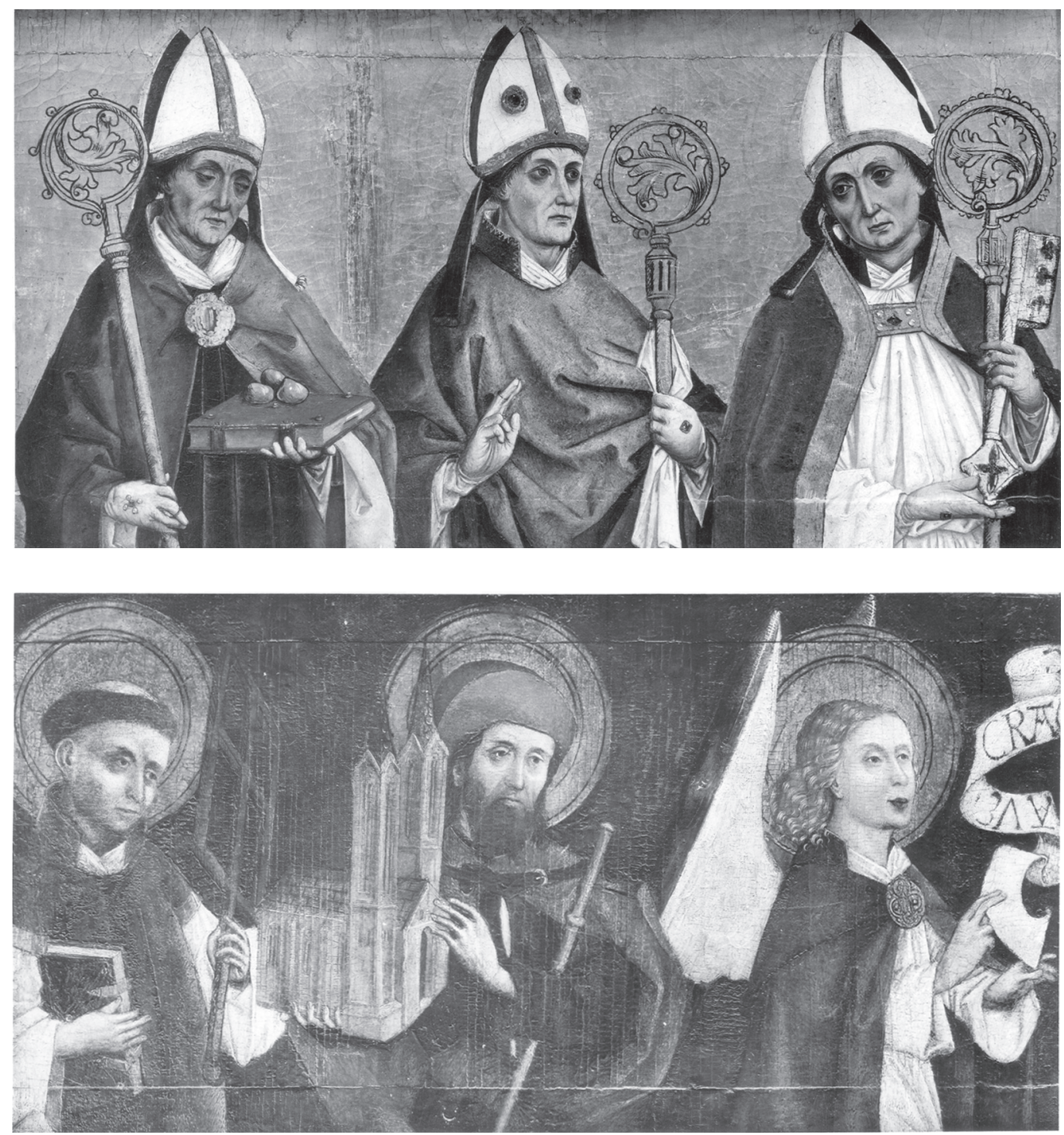

2. Panel YORAG 898a: recto and verso sides; York Art Gallery (current location unknown)

a black cloak, as if he was a Dominican friar - so in spite of the staff the identification as St Anthony ${ }^{3}$ is most likely erroneous. This figure has also been identified as St Dominic ${ }^{4}$, or more recently as St Thomas Aquinas. ${ }^{5}$ In fact, St Dominic seems to be the most probable option, as according to the „Golden Legend” a set of book and staff was given to that saint by St Peter and St Paul ${ }^{6}$ (St Dominic's staff is still preserved as a relic in the monastery church

\footnotetext{
${ }^{3}$ Proposed in York Art Gallery Catalogue..., pp. 89-90.

${ }^{4}$ Peter STRIEDER, „Miszellen zur Nürnberger Malerei des 15. Jahrhunderts”, in: Anzeiger des Germanischen Nationalmuseums (1975), p. 44.

${ }^{5}$ Robert SUCKALE, Die Erneuerung der Malkunst vor Dürer, Petersberg 2009, vol. 2, p. 117, cat. no. 38.

${ }^{6}$,And on a time as he prayed at Rome in the church of St Peter for the increasing of his order, he saw coming to him the glorious princes of the apostles, Peter and Paul, and him seemed that Peter gave to him the staff first, and St Paul delivered to him the book, and they said to him: Go and preach, for thou art chosen of God to do that occupation and ministry, and in a little moment him seemed that he saw his sons spread throughout the world, two and two, preaching to the people the word of God.” (,The Life of Saint Dominic”, in: The Golden Legend or Lives of the Saints, Compiled by Jacobus de Voragine, Archbishop of Genoa, 1275 Englished by William Caxton, First Edition 1483, vol. IV, pp. 82-93).
} 

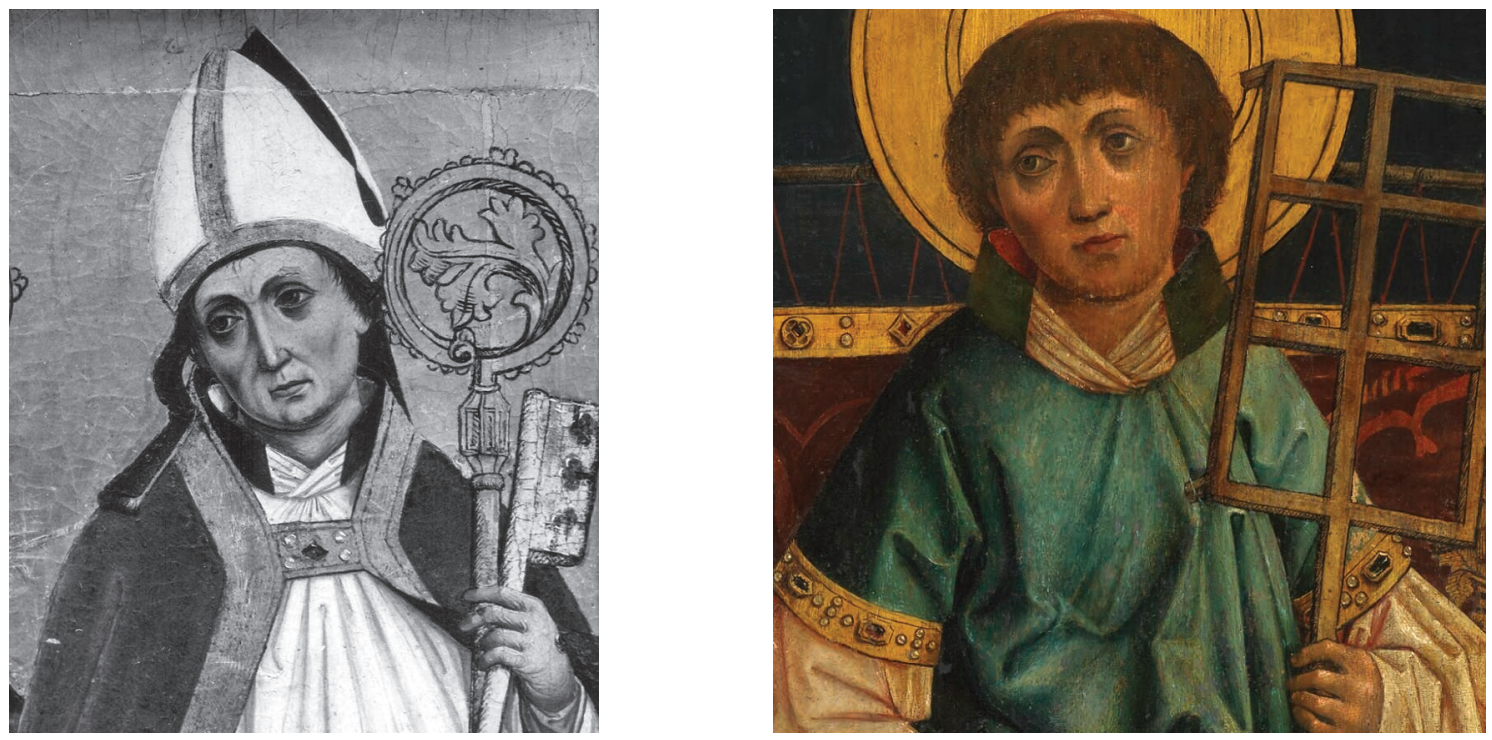

3. A comparison of the details of recto side of panel YORAG 898 a (present location unknown, fig. 2) and an altar-wing from Saint Catherine of Siena Retable, 1464, Hans Pleydenwurff and workshop (Nuremberg, Germanisches Nationalmuseum, Gm139, detail of fig. 11)
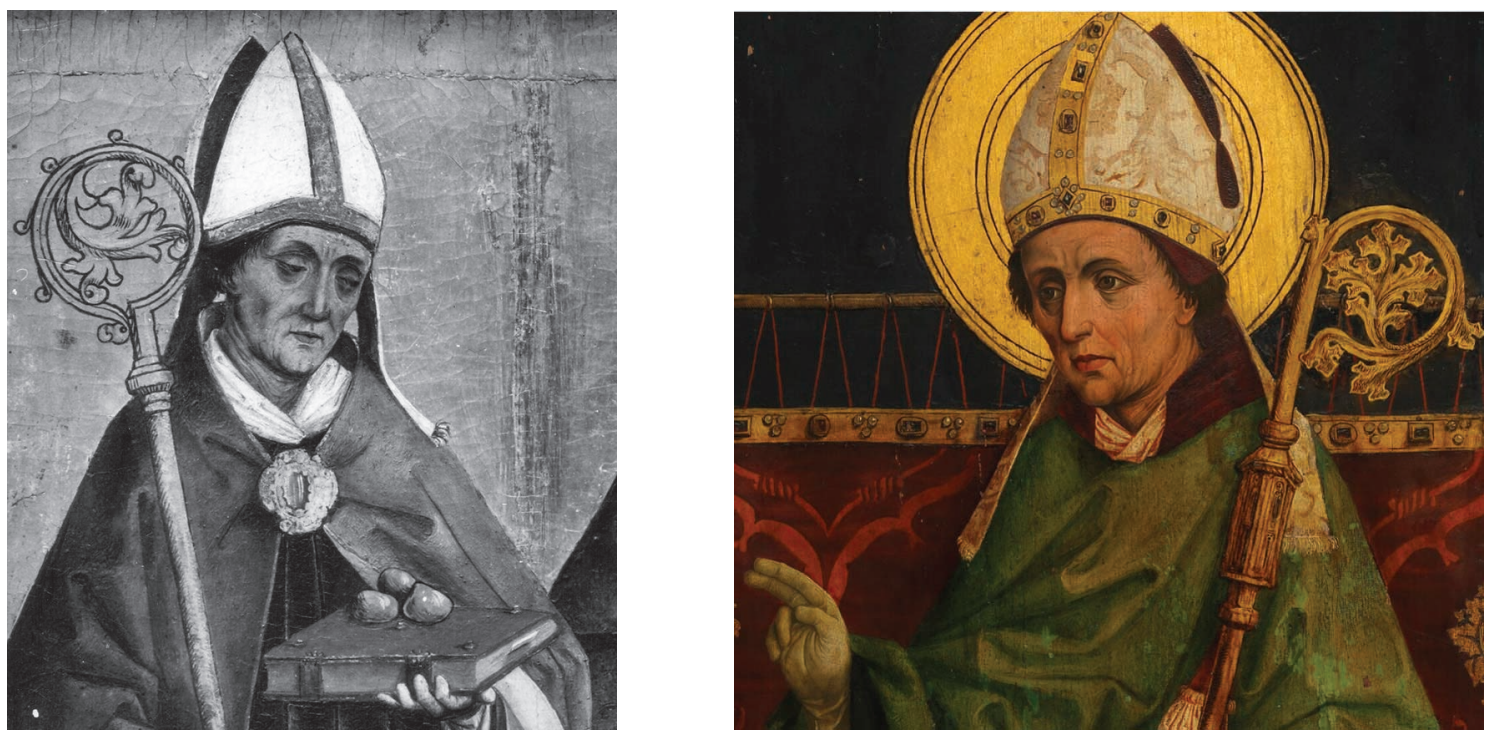

4. A comparison of the details of recto side of panel YORAG 898 a (present location unknown, fig. 2) and an altar-wing from Saint Catherine of Siena Retable, 1464, Hans Pleydenwurff and workshop (Nuremberg, Germanisches Nationalmuseum, Gm140, detail of fig. 11)

at Silos). ${ }^{7}$ Usually in gothic art St Dominic was depicted with a lily rather than with a staff and book - those attributes became much more popular for him in baroque art. $^{8}$

The verso side of the same panel is composed in a very similar way: one male and two female saints are depicted half-length, but this time against a dark background. To the left St Catherine of Siena is turning slightly right; dressed as a tertiary of the Dominican Order, she is holding a book and a crucifix embedded in a heart. St Ursula, depicted in the middle,

\footnotetext{
${ }^{7}$ On the staff in reference to St Dominic and his veneration see Anthony LAPPIN, The Medieval Cult of Saint Dominic of Silos, Leeds 2002, pp. 58 and 197-204.

${ }^{8}$ Das Lexikon der christlichen Ikonographie, vol. 6, Roma-Freiburg-Basel-Wien 1974, pp. 74-79.
} 

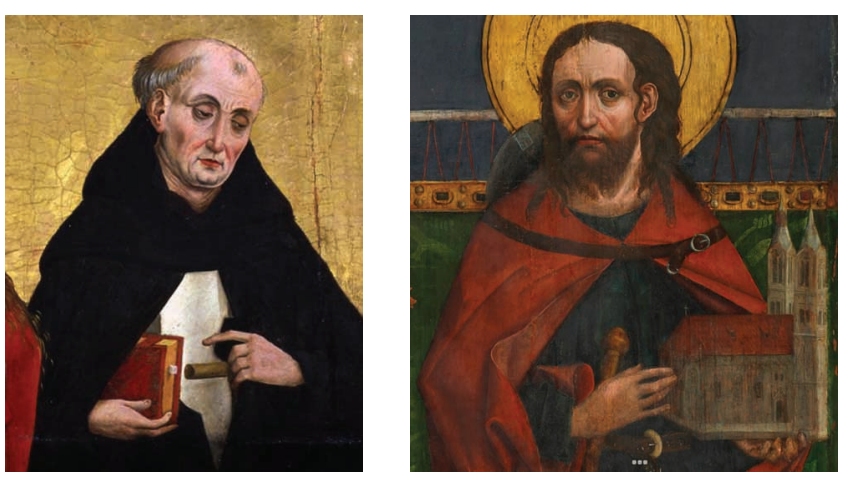

5. A comparison of the details of recto side of panel YORAG $898 \mathrm{~b}$ (York Art Gallery) and an altar-wing from Saint Catherine of Siena Retable, 1464, Hans Pleydenwurff and workshop (Nuremberg, Germanisches Nationalmuseum, Gm138, detail of fig. 11)

is turning left; she is crowned, wearing a green dress and a red cloak, and she holds an arrow in her right hand. The third saint, depicted to the right and turned slightly right, is a Dominican friar with a lily in his hand, and a white Dove of the Holy Spirit by his ear. However he has been described as St Dominic, ${ }^{9}$ it seems more likely that it is in fact St Thomas Aquinas, ${ }^{10}$ whose attribute was the Dove, and who may also have been depicted as holding a lily. Nevertheless, St Thomas Aquinas should also be depicted with the book, which is absent in the case of the panel in York. ${ }^{11}$

The other panel, now lost due in the theft in 1979, contained three half-figure depictions of Saints Bishops on the recto side (against the golden background). The bishop to the left, turned slightly right, was St Nicolas, holding a book with three golden balls. The one to the right, who was holding a key, should be identified as St Servatius. ${ }^{12} \mathrm{He}$ was a bishop of Tongeren living in the fourth century and a patron saint of the city of Maastricht - his attribute is a key, as according to the legend St Peter handed the Keys to the Heaven to him. ${ }^{13}$ St Servatius' cult was present in the late medieval Germany as well, and he was venerated in the fifteenth century Nuremberg; one of the examples of the depictions of this saint (actually inscribed «S Servatius») is an altarpiece wing from the Altar of St Wolfgang in St Lawrence Church in Nuremberg, dateable to ca. $1460 .{ }^{14}$ The most problematic is the bishop depicted in the middle of the panel - he does not have any particular attribute, just a crosier. Robert Suckale proposed St Adelphus of Metz, who was supposed to be so wellknown and venerated in Nuremberg, that he would not need to be depicted with any attribute. ${ }^{15}$ However, it should be noted that unlike the two saints by the sides of the panel, the Bishop Saint in the middle was wearing a chasuble, and his mitre was decorated with two precious stones. That may indicate a higher rank of that saint in comparison to St Nicholas and St Servatius; perhaps St Augustine, tentatively suggested by Peter Striedel, ${ }^{16}$ would be a better choice. The verso side of that panel contained the depictions of St Lawrence (to the left) and St Sebald (in the middle), who were the patron Saints of Nuremberg. By the right edge the Archangel Gabriel was holding a banner with his greeting

\footnotetext{
${ }^{9}$ York Art Gallery Catalogue..., pp. 89-90; SUCKALE, op. cit., vol. 2, p. 117, cat. no. 38, endnote 1682.

${ }^{10}$ STRIEDER, op. cit., p. 44.

${ }^{11}$ Louis RÉAU, Iconographie de l'art chrétien, Paris 1958, vol. III, p. 1278 lists the Dove as the main attribute of St Thomas Aquinas (not mentioning the book as a necessary second attribute).

12 York Art Gallery Catalogue..., p. 90 identifies him as St Germain of Paris, which is a mistake.

${ }^{13}$ See Hendrik VAN VELDEKE et al (eds.), The Life of Saint Servatius: A Dual-language Edition of the Middle Dutch «legend of Saint Servatius» by Heinrich Von Veldeke and the Anonymous Upper German «life of Saint Servatius», Lewiston N.Y. 2006.

${ }^{14}$ Peter STIREDER, Tafelmalerei in Nürnberg 1350-1550, Königstein im Taunus 1993, p. 189, cat. no. 33.

15 SUCKALE, op. cit., vol. 2, p. 122, cat. no. 38.

${ }^{16}$ STRIEDER, op. cit., p. 44.
} 
(AVE GRA[tia]) - undoubtedly there must have been another panel with the depiction of the Virgin, completing the scene of Annunciation.

It seems that the York panels were painted by at least two artists: one of them (let's call him Master A) created the depictions at the inner sides of the wings (with the golden background) and the other (in this case - Master B) painted the outer sides. Both Masters painted the faces with long and straight noses, sunken cheeks, round chins, rather small lips and round eyes, with distinctive upper and lower eyelids, marked with deep shadows. However, the faces painted by Master A are characterised by a sharper chiaroscuro and more precise execution of the facial details (e.g. the wrinkles) compared to the work of Master B. There should be no doubt that Master A was the same painter who created the panels from the altar of St Catherine of Siena from St Catherine's church in Nuremberg. ${ }^{17}$ The comparison of the panels from the St Catherine of Siena altar with the recto sides of the panels from York shows the same way of depicting the faces (both in features and in style), the folds of the clothes and the halos around saints' heads (they are barely visible now in the panel in York, but were previously marked more distinctively with a double line), as well as the saints' hands (Figs. 3, 4 and 5). Both works have been painted on pine panels.

The altar of St Catherine of Siena was completed in 1464, most likely by the workshop of Hans Pleydenwurff, to the St Catherine's Church (which was the church of the Dominican Nuns' Convent) in Nuremberg. The church was closed during the Reformation in the sixteenth century; it was put to profane use in the seventeenth century and destroyed in 1945 (only the ruins remain today). Also the other Nurembergian Dominican Church, the one of the male convent, was closed due to the Reformation - it was transformed into St Lawrence church and finally dissolved at the beginning of the nineteenth century. Most of what survived from the numerous altars from both churches is now in the Germanisches Nationalmuseum in Nuremberg. ${ }^{18}$ The oldest descriptions of the St Catherine of Siena retable date back to the eighteenth century. ${ }^{19}$ By the early nineteenth century the central part of that altar probably got lost, while only the wings were recorded in the Our Lady church in Nuremberg, separated and combined with some other panels into the new retables. ${ }^{20}$ After the restoration of the Our Lady church in 1879-81 they were removed; they were loaned to and subsequently acquired by the Germanisches Nationalmuseum in $\mathrm{Nu}-$ remberg (1906). Nothing is known about the history of the predella of this altar.

The York panels have been published independently in England and in Germany - it seems that the authors from both countries have never made any reference to each other's

\footnotetext{
${ }^{17}$ York panels are actually considered by German scholars as parts of the Catherine of Siena altarpiece (SUCKALE, op. cit., vol. 2, pp. 117-123, cat. no. 38, ill. 856-857); on that subject see below, notes 24 and 25.

${ }^{18}$ Hans ROSER, Klöster in Franken, Freiburg 1988, 270; see also Barbara STEINKE, Paradiesgarten oder Gefängnis? Das Nürnberger Katharinenkloster zwischen Klosterreform und Reformation, (Spätmittelalter und Reformation. Neue Reihe, 30), Tübingen 2006. On the panels in Germanisches Nationalmuseum in Nuremberg see below, note 37.

${ }^{19}$ Nürnbergisches Zion, das ist wahrhaffte Beschreibung aller Kirchen und Schulen in- und außerhalb der Reichsstadt Nürnberg, Nürnberg 1733, p. 123 [„,Auf den zur lincken Hand ist von Bildhauer Arbeit in der mitten Catharina de Senis, welche auf beeden Seiten auch 2. Heilige hat, auf den rechten Altar-Deckel ist S. Bernardus, auf den lincken ein mir unbekannter Heiliger.']; Christoph Gottlieb VON MURR, Beschreibung der vornehmsten Merkwürdigkeiten in des H.R. Reichs freyen Stadt Nürnberg..., Nürnberg 1778, p. 294 [„Auf dem kleinen Altare zur linken Hand ist in der Mitte Katharina von Siena von Bildhauerarbeit, die zwichen zween Heiligen stehet. Auf dem rechten Altardeckel ist inwendig St. Bernhard, auf dem linken ein anderer Heiliger. Aussen ist St. Sebald und Laurentius, zwischen zween Bischöfen. Am Reliquienschranke sind acht Heilige, Halbfiguren, sehr schön gemaltet"]. See also below, note 39.

20 The depictions of St Anthony and St Adolphus with the parts of Tucher-altar and St Sebald and St Lawrence with the Epitaph of Wolf von Wolfsthal (SUCKALE, op. cit., vol. 2, p. 117, cat. no. 38).
} 
6. Hans Pleydenwurff, Deposition, from the high altar for St-Elisabeth Church in Wroctaw, 1462, Germanisches Nationalmuseum in Nuremberg, Gm1127, http://objektkatalog.gnm.de/objekt/ Gm 1127

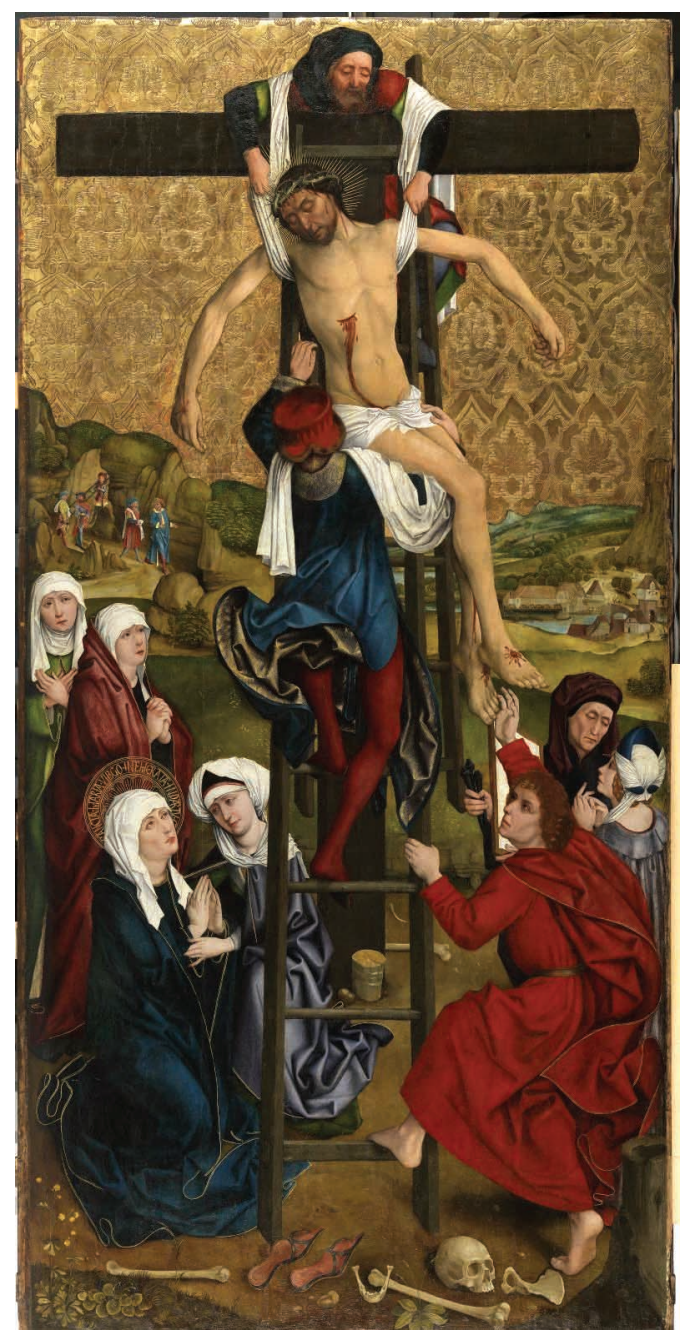

work. In Germany in 1957 the panels were mentioned as being in Arcade Gallery in London $^{21}$ and subsequently all the later German publications refer to the panels as the wings of predella of an unknown location (,last seen in Arcade Gallery in 1956”). Peter Strieder attributed the panels to the circle of Michael Wolgemuth and noted their relation to the altar-wings in the Germanisches Nationalmuseum in Nuremberg, which are the mentioned above remains of the St Catherine of Siena retable from the Dominican St Catherine church in Nuremberg. ${ }^{22}$ Robert Suckale at first ascribed the panels to the „Nurembergian co-worker of Hans Siebenbürger" - the latter was supposed to be a painter of Transylvanian origin, who worked in the atelier of Hans Pleydenwurff and later became a main artist of the workshop that created the famous Vienese Schotten-Altar. ${ }^{23}$ However, in his last comprehensive monograph of the Nuremberg painting before Dürer, Robert Suckale attributed the whole St Catherine of Siena Altarpiece to Hans Pleydenwurff and his workshop,

\footnotetext{
${ }^{21}$ Die Weltkunst. Illustrierte Zeitschrift für Kunst, 27, 8 (1957), p. 21.

${ }^{22}$ STRIEDER, Miszellen zur Nürnberger Malerei..., pp. 43-44.

${ }^{23}$ Robert SUCKALE, ,Der Maler Johannes Siebenbürger (um 1440-1483) als Vermittler Nürnberger Kunst nach Ostmitteleuropa", in: E. Wetter (ed.), Die Länder der böhmischen Krone und ihre Nachbarn zur Zeit der Jagiellonenkönige (1471-1526). Kunst - Kultur - Geschichte, Ostfildern 2004, p. 372. See also Magdalena ŁANUSZKA, ,An attribution for two late Gothic central-European panels, in English public collections, depicting episodes from the life of St. Barbara", in: Quart 2(48) (2018), pp. 3-20.
} 

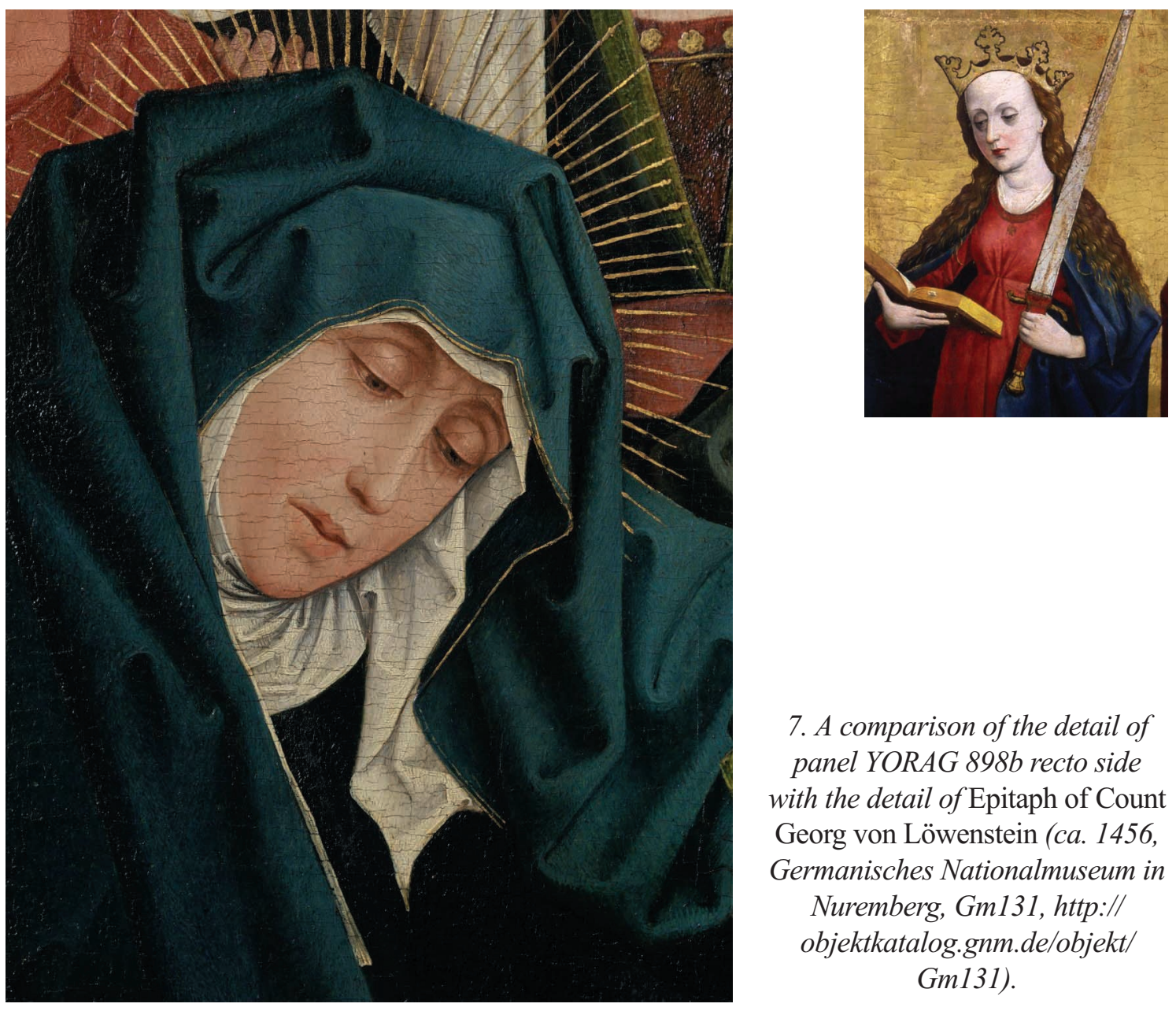

\section{A comparison of the detail of} panel YORAG $898 \mathrm{~b}$ recto side with the detail of Epitaph of Count Georg von Löwenstein (ca. 1456, Germanisches Nationalmuseum in Nuremberg, Gm131, http:// objektkatalog.gnm.de/objekt/ Gm131).

assuming that the York panels in question were the wings of its predella. ${ }^{24}$ That attribution was also accepted by the Germanisches Nationalmuseum in Nuremberg. ${ }^{25}$ Meanwhile, British publications on the panels only describe the paintings as German School or Nurembergian School, with no reference to the possible connections to Hans Pleydenwurff and his workshop at all. ${ }^{26}$

Hans Pleydenwurff came from a Bamberg family; he moved to Nuremberg in $1457 .{ }^{27}$ Although his workshop seems to have been one of the most important ones in Nuremberg

\footnotetext{
${ }^{24}$ SUCKALE, Die Erneuerung..., vol. 2, pp. 117-123, cat. no. 38, ill. 856-857. The entry contains a date misspell in the predella's history, as it states that the panels were in the British art market in 1965 (which was supposed to be 1956).

${ }^{25}$ Daniel HESS, Dagmar HIRSCHFELDER, Katja von BAUM (Eds.): Die Gemälde des Spätmittelalters im Germanischen Nationalmuseum, vol. I: Franken, Regensburg 2019, Cat. no 30, pp. 415-432. This new catalogue of the medieval paintings in Germanisches Nationalmuseum is a result of the project Die deutsche Tafelmalerei des Spätmittelalters (an extensive research project, sponsored by the Leibniz Association, on German panel painting of the late Middle Ages launched the Germanisches Nationalmuseum in April 2013; the Head of the Project is Dr. Dagmar Hirschfelder). In this catalogue the predella panels in question are already described correctly as belonging to the collection of York Art Gallery. I would like to thank dr. Beate Fücker of Germanisches Nationalmuseum, as well as Susanne Wagner and Judith Hentschel for their kind support of my work.

${ }^{26}$ PREVIEW. City of York Art Gallery Quarterly 40 (October 1957), vol. X, p. 390, ill. p. 393; York Art Gallery Catalogue, pp. 89-90, plate 78; Oil Paintings in Public Ownership. North Yorkshire, London 2006, p. 285.

${ }^{27}$ See STRIEDER, Tafelmalerei in Nürnberg ..., 52-59, Robert SUCKALE, „Probleme um den „Meister von 1486”, in: K. Bernhardt, P. Piotrowski (eds.), Grenzen überwindend: Festschrift für Adam S. Labuda zum 60. Geburtstag, Berlin 2006, pp. 212-222, and lately SUCKALE, Die Erneuerung..., vol. 1, p. 103.
} 

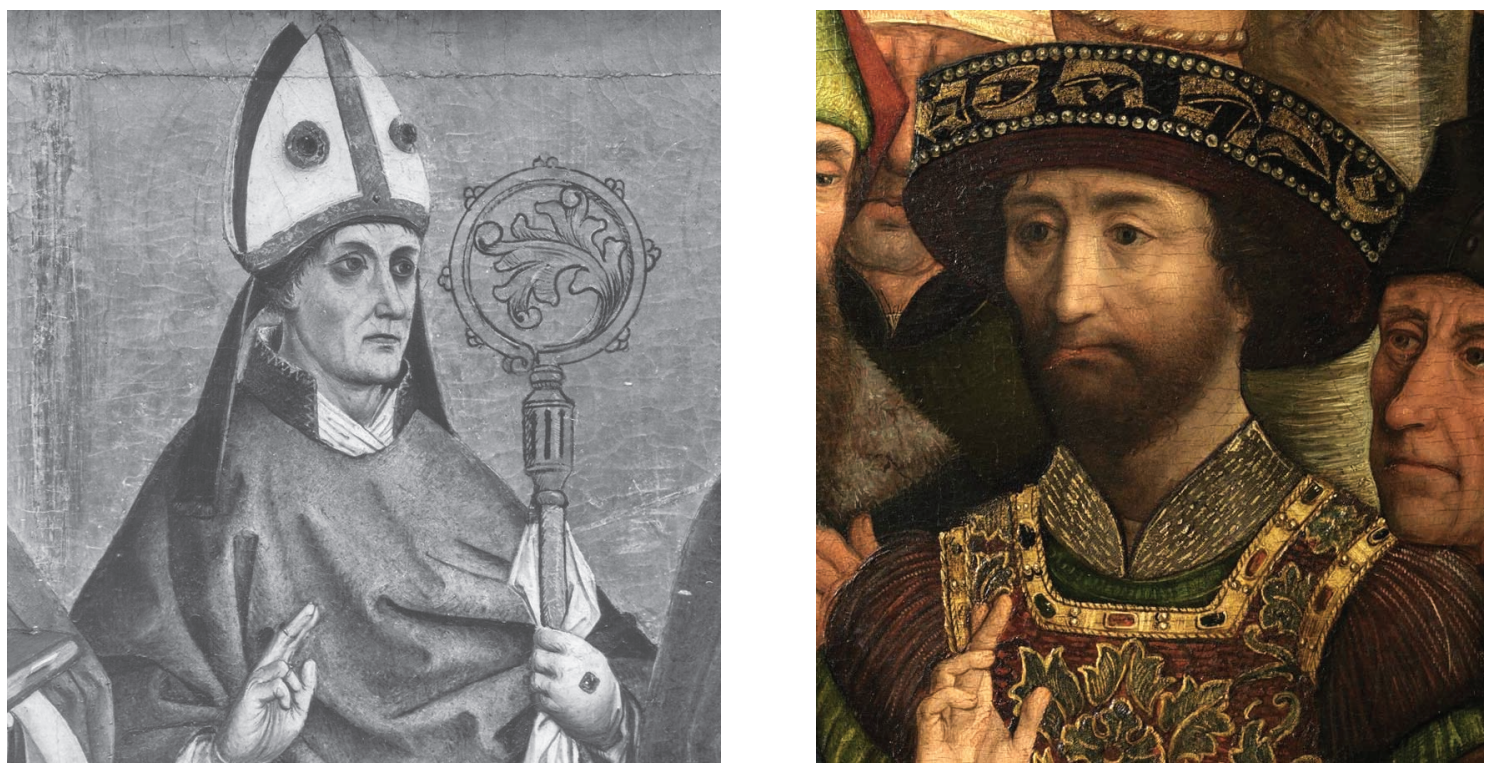

8. A comparison of the details of recto side of panel YORAG 898 a and Epitaph of Count Georg von Löwenstein, ca. 1456, (Nuremberg, Germanisches Nationalmuseum, Gm131, http:// objektkatalog.gnm.de/objekt/Gm131)

in the third quarter of the fifteenth century, we know very little about it - there are no records on its location or how many people were employed there. In 1462 Hans Pleydenwurff completed the commission of the high altar for the St-Elisabeth Church in Wrocław - two panels survive from that retable ${ }^{28}$ and it is actually the only documented piece of art by Hans Pleydenwurff (Fig. 6). Nevertheless, stylistic and technical analysis enable many other pieces of art to be attributed to his workshop. That workshop certainly employed many artists, as the pieces of art attributed to Pleydenwurff's atelier often show some differences and individual character of various painters, in spite of following the style of the master. ${ }^{29} \mathrm{It}$ seems very likely that Hans Pleydenwurff knew early Netherlandish art, especially the art of Rogier van der Weyden and Dirk Bouts. Although there are no written sources that would prove Pleydenwurff's trip to the Netherlands, his paintings show that he was familiar with the art of those famous masters; he introduced many Netherlandish motifs to Nuremberg art. Hans Pleydenwurff died in 1472 and his workshop was taken over by Michael Wolgemuth, who married Pleydenwurff's widow, and later was a teacher of Albrecht Dürer.

\footnotetext{
${ }^{28}$ The altarpiece was hit by the lightning in the late fifteenth century and probably partly destroyed back then; it was later replaced with the baroque retable (in the seventeenth century). The survived panels are the Deposition, which is now in Germanisches Nationalmuseum in Nuremberg (GM1127: see Beate FÜCKER, Dagmar HIRSCHFELDER: Hans Pleydenwurff, Kreuzabnahme Christi, 1462, Gm1127, in: Datenbank zur Deutschen Tafelmalerei des Spätmittelalters im Germanischen Nationalmuseum, https://tafelmalerei.gnm.de/objekt/Gm1127 accessed 04.11.2019) and the fragment of the Presentation in the Temple (in National Museum in Warsaw). There used to be two other fragments in public collection in Wrocław (Crucifixion and Epiphany) but they have been lost since 1945. See Bożena STEINBORN, Antoni ZIEMBA, Malarstwo niemieckie do 1600 roku, Katalog zbiorow / Deutsche Malerei bis 1600, Nationalmuseum Warschau, Warszawa 2000, pp. 190-193, and Agnieszka PATAŁA, „Between 'Silesiae metropolim' and 'Quasi centrum Europae': The Mobility of Breslau and Nuremberg Artists in the 15th and 16th Centuries”, in: Kunsttexte.de, Ostblick 3 (2016), http://edoc.hu-berlin.de/18452/8227 [accessed 08.11.2019].

${ }^{29}$ The workshop's oeuvre was recently re-considered and comprehensively described by Robert Suckale in his 2-volume book (SUCKALE, Die Erneuerung...). As a result of this study it is concluded that Hans Pleydenwurff was actually the artist who was responsible for the growth of creativity and innovation in Nurembergian art in the second half of the fifteenth century, which subsequently created a ground for the genius of Albrecht Dürer.
} 

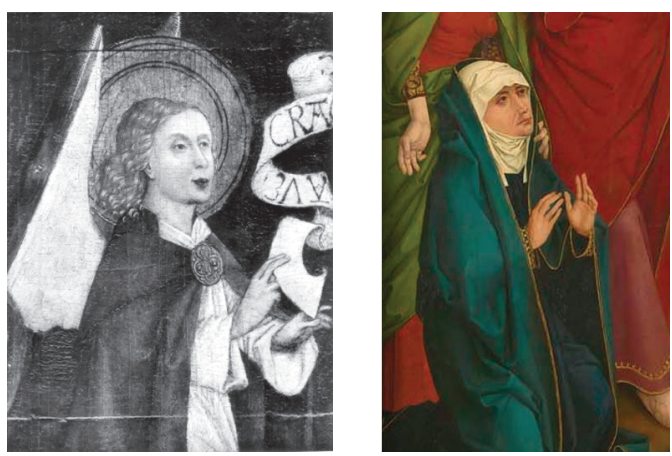

9. A comparison of the details of verso side of panel YORAG 898a and Deposition from Hof Altarpiece, 1465, Alte Pinakothek, Munich. Fot. https://www.sammlung.pinakothek.de/en/artist/ hans-pleydenwurff/hofer-altar-kreuzabnahmechristi-rueckseite-geburt-christi

The female saints from the panel in York undoubtedly resemble the type present in the other works by or attributed to Hans Pleydenwurff, both in their facial features and modelling, as well as in the forms of the angular folds of their clothes. The first example would be the Deposition from the altar of the St Elisabeth church in Wrocław (1462, Fig. 6), ${ }^{30}$ undoubtedly completed by Pleydenwurff. Similar female figures are present also in the other works attributed to Hans Pleydenwurff and his workshop (Fig. 7), such as the Nativity from the Hof Altarpiece, completed in 1465 (Alte Pinakothek, Munich), ${ }^{31}$ or the panels from the Altar of the Three Kings from the St Lawrence church in Nuremberg (ca. $1460)^{32}$ and Epitaph of Count Georg von Löwenstein with Calvary (ca. 1456, Germanisches Nationalmuseum in Nuremberg). ${ }^{33}$ Actually also among the male figures in the latter panel we may find a similar face to one of the bishops depicted in the stolen panel from York (Fig. 8).

The male saints on the recto sides of York's panels, as mentioned above, bear striking resemblance to the figures in the wings of St Catherine of Siena altarpiece from St Catherine's church, painted by artists from Pleydenwurff's workshop. Also, the verso depictions of the York panels show resemblance with works from the workshop of Pleydenwurff for example, the triangular face of Angel of the Annunciation group (YORAG 898a), with narrow and small eyes and full lips is close to the face of the Virgin from the Deposition of the Hof-Altar mentioned above (Fig. 9). On the other hand, saints from the verso sides of the York panels may be compared with some figures from the high altar of St Clara church in Bamberg (Hans Pleydenwurff and workshop, ca. 1460-62, Staatsgalerie, Bamberg), ${ }^{34}$ also having small eyes with distinctive shadows and long narrow noses. It is though justified to assume that the panels belonging to the Art Gallery in York were created by Hans Pleydenwurff's workshop, probably in the 1460s. But were they indeed part of the St Catherine of Siena retable?

\footnotetext{
${ }^{30}$ See e.g. Germanisches Nationalmuseum Nürnberg, München 1980, 161, ill. 162; STRIEDER, Tafelmalerei in Nürnberg..., pp. 52-54, cat. no. 38; SUCKALE, Die Erneuerung..., vol. 1, pp. 48-53, 105-106; vol. 2: cat. no. 10; Der frühe Dürer, Exh. Catalogue Germanisches Nationalmuseum Nürnberg, exh. cat., Nürnberg 2012, cat. no. 25.

${ }^{31}$ SUCKALE, Die Erneuerung..., vol. 1, pp. 159-161; vol. 2, cat. no. 33.

${ }^{32}$ SUCKALE, Die Erneuerung..., vol. 1, p. 106; vol. 2, cat. no. 47.

${ }^{33}$ See e.g. Robert SUCKALE, „Hans Pleydenwurff in Bamberg”, in: Bericht. Historischer Verein Bamberg für die Pflege der Geschichte des ehemaligen Fürstbistums, vol. 120, 1984, pp. 430-434; Gerhard FRITZ, Die Geschichte der Grafschaft Löwenstein und der Grafen von Löwenstein-Habsburg vom späten 13. bis zur Mitte des 15. Jh., Sigmaringen 1986, pp. 201-209; SUCKALE, Die Erneuerung..., vol. 1, pp. 104-114; vol. 2, cat. no. 42; Katja von BAUM, Dagmar HIRSCHFELDER: Hans Pleydenwurff, Kalvarienberg, um 1456, Gm131 in: Datenbank zur Deutschen Tafelmalerei des Spätmittelalters im Germanischen Nationalmuseum, https://tafelmalerei.gnm.de/objekt/Gm131 (accessed 04.11.2019).

${ }^{34}$ SUCKALE, Hans Pleydenwurff in Bamberg..., 423-438; SUCKALE, Die Erneuerung..., vol. 1, pp. 153-154.
} 


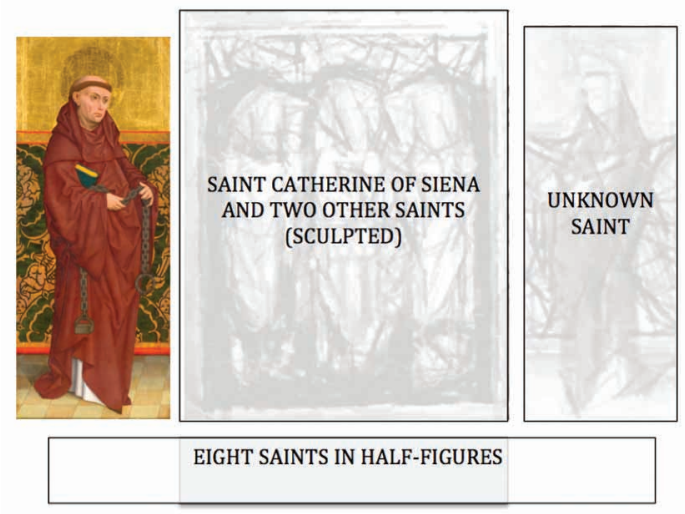

10. St Catherine of Siena altarpiece openedreconstruction by M. Lanuszka (including the wing with Saint Leonard, North Carolina Museum of Art, Raleigh NC, USA)

The altar of St Catherine of Siena used to be a pentaptych and all that is left of it are the panels from its wings. The altar was consecrated on $20^{\text {th }}$ August 1464; it contained the sculpted depiction of St Catherine of Siena and two other saints in the middle part, which unfortunately is now lost. ${ }^{35}$ The inner parts of the inner pair of this altar's wings were decorated with the full length depictions of two saints against a golden background: one of them, St Leonard, is now in the North Carolina Museum of Art, Raleigh NC, USA (gift from the Samuel H. Kress Foundation in New York). It is probable that the figures in the wings of the main opening were painted by Hans Pleydenwurff himself. ${ }^{36}$ (Fig. 10)

The middle opening of the altar was decorated with the full-length depictions of St Anthony, St Lawrence, St Sebald and probably St Adelphus of Metz, placed against a dark background and painted decorated cloth (fig. 11). Finally, the closed altar showed St Sebastian and St Florian standing in front of brick walls with the blue sky behind (fig. 12). The panels of the mid-opening and closed retable are now in the Germanisches Nationalmuseum in Nuremberg (GM137 and GM138 painted on both sides and GM139 and GM140 painted on one side) $)^{37}$ - the author of recto sides of the York panels was most likely involved in creating those Nuremberg wings. ${ }^{38}$ According to the eighteenth century descriptions, the altar of St Catherine of Siena had a predella that is said to have contained eight saints depicted in half-length. ${ }^{39}$

\footnotetext{
${ }^{35}$ Walter FRIES, „Kirche und Kloster zu St. Katharina in Nürnberg”, in: Mitteilungen des Vereins für die Geschichte der Stadt Nürnberg 25 (1924), 116. See above, note 19.

${ }^{36}$ SUCKALE, Die Erneuerung..., vol. 2, p. 123, cat. no. 38. The panel with St Leonhard, unlike the rest of the panels from that altar, has canvas under the brocade cloth part. However, the golden background as well as the cinnabar-red lines and the painted cloth were restored, and the canvas is in large parts replaced. In this case placing canvas only on the recto panel side was probably the way to make it look better than the verso sides: the painted cloth looked more realistic if there was an actual canvas underneath that part of the painting. Also, the panel with St Leonhard is $20 \mathrm{~cm}$ shorter then the other panels, but comparison of their compositions shows that he still fits the others in scale, but there is less background on top and less floor on the bottom, so it was probably cut.

${ }^{37}$ See e.g. Alfred STANGE, Deutsche Malerei der Gotik, vol. 9, München/Berlin 1958, p. 51; STRIEDER, Miszellen zur Nürnberger Malerei..., pp. 42-44; STRIEDER, Tafelmalerei in Nürnberg..., cat. no. 37; SUCKALE, Die Erneuerung..., vol. 1, pp. 113, 165, 199; vol. 2, cat. no. 38, and most recently HESS, HIRSCHFELDER, von BAUM (Eds.): Die Gemälde des Spätmittelalters..., Cat. no 30, and entries in Datenbank zur Deutschen Tafelmalerei des Spätmittelalters im Germanischen Nationalmuseum (https://tafelmalerei.gnm.de/objekt/Gm137, https://tafelmalerei.gnm.de/objekt/ Gm138, https://tafelmalerei.gnm.de/objekt/Gm139 and https:/tafelmalerei.gnm.de/objekt/Gm140, accessed 4.11.2019). ${ }^{38}$ SUCKALE, Die Erneuerung..., vol. 2, p. 123, cat. no. 38 divides the authorship of the inner and outer parts of the outer wings between two painters.

${ }^{39}$ MURR, op.cit., p. 294 (see above, note 19); repeated by FRIES, op.cit., p. 116 [„,Altar. Die heilige Katharina von Siena zwischen zwei Heiligen, Mittelfeld (Schnitzwerk). Innenflügel, bemalt: St. Bernhard und ein unbekannter Heiliger.
} 

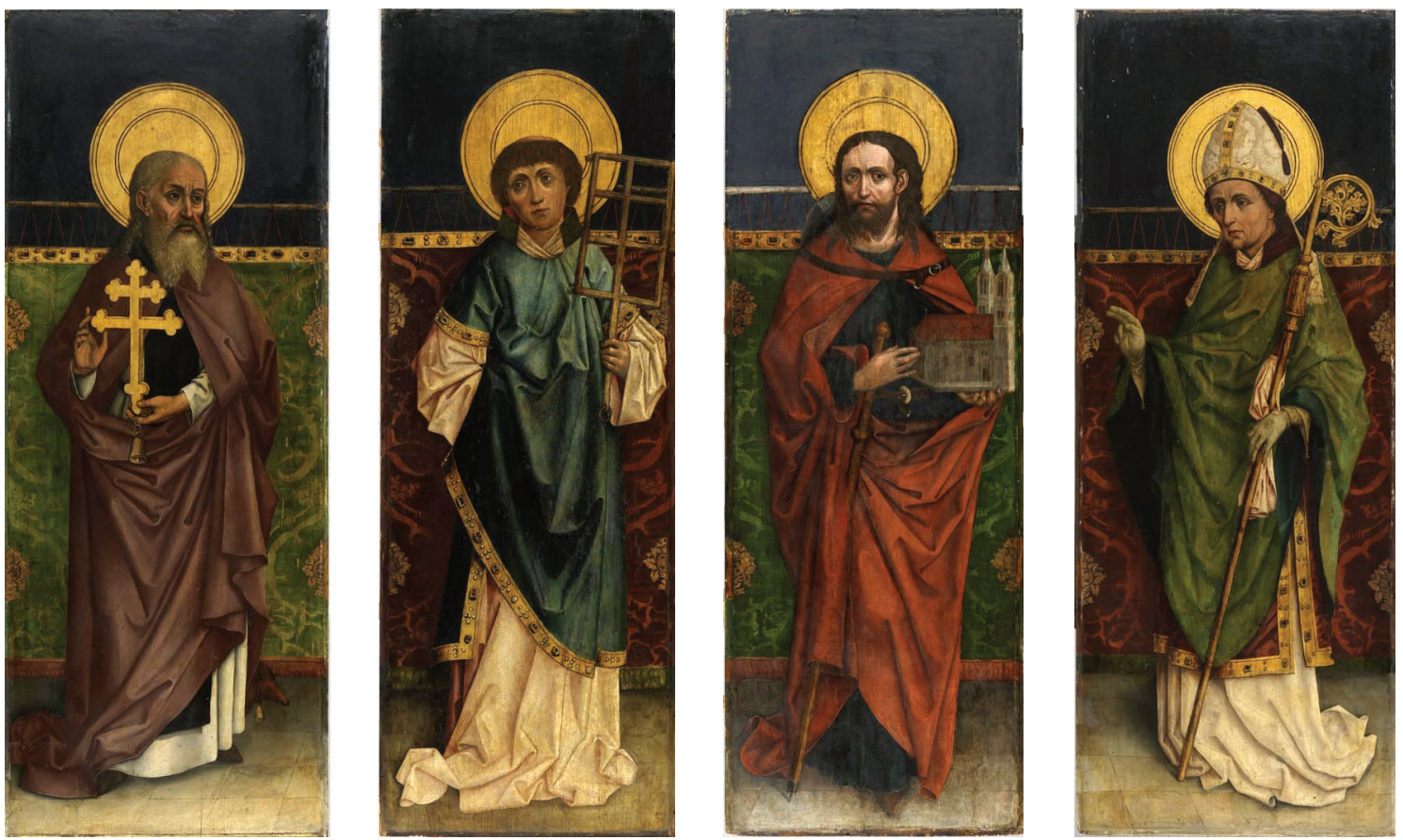

11. Hans Pleydenwurff and workshop, Saint Catherine of Siena Retable, 1464, middle openingreconstruction, Nuremberg, Germanisches Nationalmuseum, Gm137 (http://objektkatalog.gnm.de/ objekt/Gm137), Gm138 (http://objektkatalog.gnm.delobjekt/Gm138), Gm139 (http:// objektkatalog.gnm.delobjekt/Gm139) and Gm140 (http://objektkatalog.gnm.delobjekt/Gm140).

In late-medieval Germany altarpieces were generally made of wood, often with sculptures in the shrine and reliefs and paintings on the wings. Before World War II it was estimated that more than 3000 Gothic altar retables were still preserved in the German Reich, yet it was only a fraction of the original inventory; on the eve of the Reformation the biggest cathedrals housed over 50 altars each. ${ }^{40}$ There are various theories about the origin of late-gothic winged altarpieces, but none of those theories is unanimously approved. ${ }^{41}$ The oldest winged sacral structures are probably from the late twelfth century: usually single figures housed in the tabernacles, consisting of baldachin with solid back wall and hinged wings. ${ }^{42}$ In the thirteenth century the popular items were ivory or metal small panelled diptychs, triptychs, and polyptychs with scenes in low relief that unfold for priva-

Außenflügel: St. Sebald und St. Lorenz zwischen zwei Bischöfen; Predella: acht Heilige, Halbfiguren.”]. Apparently, the descriptions of the opened retable state that there were sculpted Catherine of Siena and two other saints in the middle part of the altar, and on the wings there were St Bernhard and the other unknown saint; when the wings were closed, they contained St Sebald, St. Lawrence, and two Bishops. It is assumed that St Leonhard was mistaken for St Bernhard in those publications, although he is actually inscribed in his halo, and so was probably the other saint, described as „unknown saint”(?). We must remember though that the St Leonhard panel is now much restored and the golden background and halo have been renewed, so it is likely that in the eighteenth and the early nineteenth centuries the panels were in such a bad condition that both inscriptions were unreadable.

${ }^{40}$ Rainer KAHSNITZ, Carved Splendor: Late Gothic Altarpieces in Southern Germany, Austria, and South Tirol, Los Angeles 2006, p. 9.

${ }^{41}$ See Karl-Werner BACHMANN, Géza JÁSZAI, Friedrich Kobler, Catheline PÉRIER-D’IETEREN, Barbara ROMMÉ, Norbert WOLF, „Flügelretabel”, in: Reallexikon zur Deutschen Kunstgeschichte, Bd. IX (2003), Sp. 1450-1536.

${ }^{42}$ Hans WENTZEL, Der Hochaltar in Cismar und die lübeckischen Chorgestühlswerkstätten des 14. Jahrhundert, Lübeck 1937, pp. 37-39; Eberhard HEMPEL, „Der Flügelaltarschrein, ein Stück deutscher, vlämischer und nordische Kunst”, in: Jomsburg 2 (1938), pp. 140 and 143; see also Peter TÅNGBERG, Mittelalterliche Holzskulpturen und Altarschreine in Schweden, Stockholm 1986, pp. 32-41. This form persisted in Franconia until the fifteenth century. 

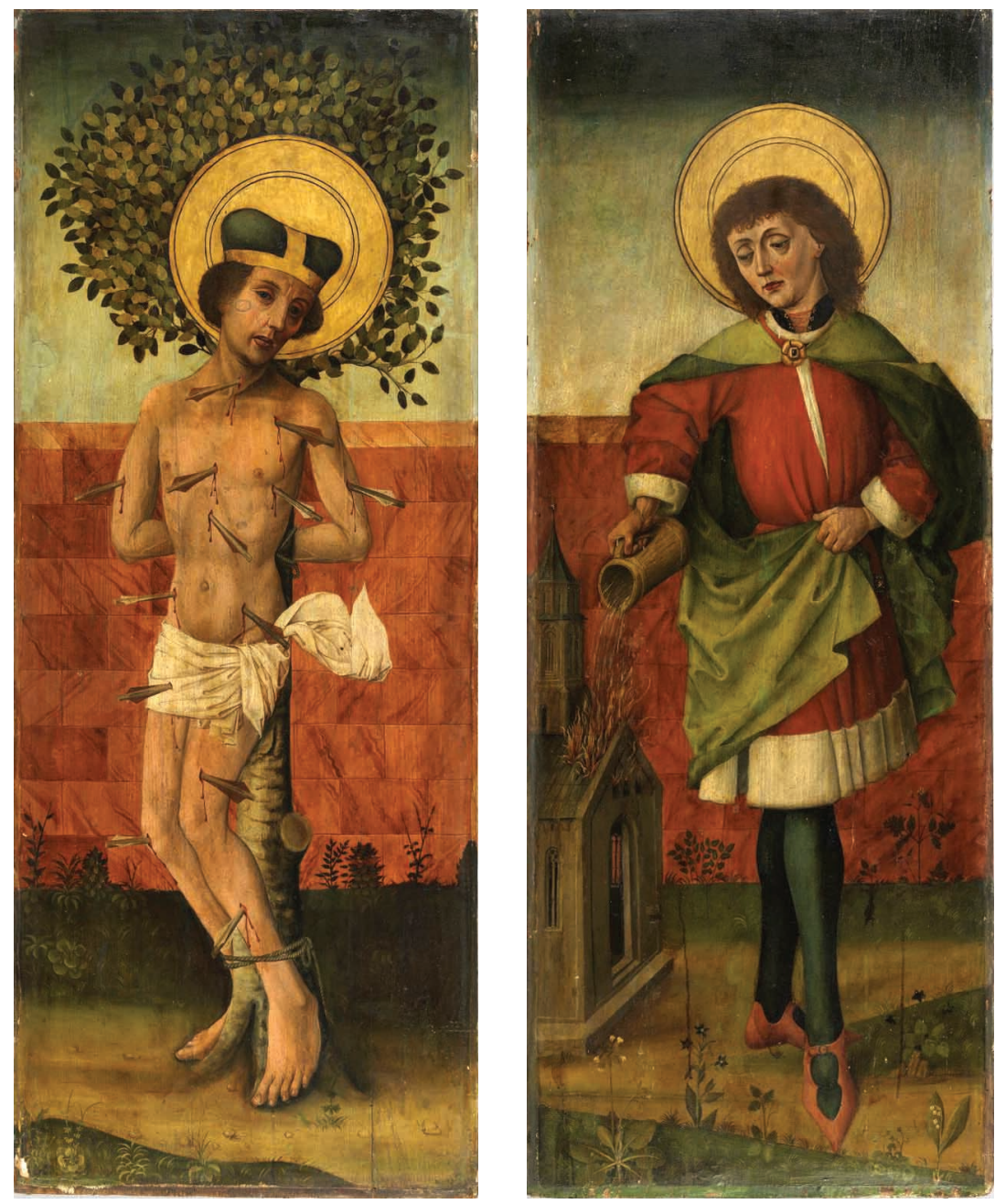

12. Hans Pleydenwurff and workshop, Saint Catherine of Siena

Retable, 1464, closed-reconstruction, Nuremberg, Germanisches Nationalmuseum, Gm137 (http://objektkatalog.gnm.de/objekt/Gm137) and Gm138 (http://objektkatalog.gnm.de/objekt/Gm138).

te meditation, and some scholars have derived later altarpiece forms from those small pieces. ${ }^{43}$ Perhaps the winged-altarpiece evolved from two-door reliquaries of the thirteenth century; ${ }^{44}$ it should be noted that the relics were exhibited on feast days on the altar, so it was natural to place the cabinet containing the relics on the altar table to present it to the public. ${ }^{45}$ The models for the wing-retables may have also been the sacristy cabinets with their compartments for relics and with decorated doors. ${ }^{46}$

Very few fourteenth century retables survive in Germany, and most of them are found in small churches in Northern Germany. In Nuremberg there is only one: an Altarpiece of

\footnotetext{
${ }^{43}$ Georg DEHIO, Geschichte der deutschen Kunst, vol. 2, Berlin 1921, p. 112; HEMPEL, op. cit., p. 141. The idea was denied e.g. by Karl SCHULTZ, Der deutsche Altar im späten Mittelalter, Würzburg 1939, p. 61.

${ }^{44}$ DEHIO, op. cit., p. 111.

${ }^{45}$ WENTZEL, op. cit., pp. 38, 40, 42; see also Wilhelm WEGNER, Der deutsche Altar des späten Mittelalters (Münchner Beiträge zur. Kunstgeschichte, Bd. 7), München 1941, p. 12.

${ }^{46}$ Harald KELLER, „Der Flügelaltar als Reliquienschrein” in: Studien zur Geschichte der Europäischen Plasik: Festschrift Theodor Müller, München 1965, pp. 125-144; see also Bernhard DECKER, ,Zur geschichtlichen Dimension in Michael Pachers Altären von Gries und St. Wolfgang", in: Städel-Jahrbuch 6 (1977), p. 306.
} 
the Order of Teutonic Knights (Deutschordensaltar) in St James Church (St. Jakob; ca. 1365-70). ${ }^{47}$ Most of the preserved German altarpieces date back to the second half of the fifteenth century, or later. ${ }^{48}$ At first relics were often placed in the altarpiece's shrine; an interesting example of this is "Saints' busts" reliquaries placed in the retable in the high altar of the former Cistercian abbey church in Marienstatt, Westerwald, Cologne (ca. 1350). ${ }^{49}$ Around the end of the fourteenth century it was not so popular anymore to place reliquaries in the centre shrine of the altars - they were kept in predellas. ${ }^{50}$ Following the design of the main part of the retable, predellas were also often decorated in relief in their central part, and supplemented by painted wings on their sides. The use of such a structure in Nuremberg in the first half of the fifteenth century is exemplified by the Deochar Altar (Deocarusaltar) in St Lawrence Church (Nuremberg, before 1437, fig.13). ${ }^{51}$

A very important function of the winged altarpiece was the ability to change images in the course of the liturgical year, as well as hiding and revealing the relics. ${ }^{52}$ Surprisingly, it seems that opening and closing the altars was not a part of the liturgy, but was just done before and after the service. ${ }^{53}$ Sacristan's rule books for the Parish Churches St Sebald (c.1482), and St Lawrence (1493) in Nuremberg say that the wings of the altarpieces were to be opened only on specific feast days, so in fact just a few days every year. ${ }^{54}$ Occasionally only the predella wings were opened. For example, the instructions of St Lawrence church say that both the main altar (Laurentius altar) as well as the altar of Our Lady should have an opened shrine and predella on the feast of the Annunciation, but the predella of the high altar should be opened on the feast of the Canonization of Emperor Henry and the Death of the Emperor Henry, as well as on the days of St Cyprian, St Otto and during the Octave of Epiphany. The Altarpiece of the Apostles were opened (both shrine and predella) on Apostles feasts, although on the feast of the Chair of St. Peter and on the day of St Matthias (during Lent) only the predella should be opened. ${ }^{55}$ We can be sure though that winged predellas were popular in fifteenth century Nuremberg. Unfortunately, in many cases only fragments of those retables survive. An example of horizontal predella-wings decorated with the half-figures of the saints are the panels from the Tucher Altarpiece (ca. 1440/50, now in the Germanisches Nationalmuseum, Nuremberg: GM 120 and 121). ${ }^{56}$

\footnotetext{
${ }^{47}$ Christian HECHT, „Der Hochaltar von St. Jakob in Nürnberg”, in: Denkmalpflege in Mittelfranken. Denkmalprämierung des Bezirks Mittelfranken (2004), p. 135.

${ }^{48}$ KAHSNITZ, op.cit., p. 10.

${ }^{49}$ Eduard TRIER, „Der St.-Ursula Altar in Marienstatt”, in: Marienstatter Gesammelte Aufsätze. Festschrift zum 750Jährigen Gründungsjubiläum 1212-1962, Marienstatt 1962, pp. 29-33.

${ }^{50}$ KAHSNITZ, op.cit., p. 24.

${ }^{51}$ Heinz STAFSKI, „Der Zwölfboten-Deocarusaltar in der St. Lorenzkirche zu Nürnberg”, in: Anzeiger des Germanischen Nationalmuseums (1992), pp. 144-174.

52 Joseph BRAUN, Der christliche Altar in seiner geschichtlichen Entwicklung, vol. 2: Die Ausstattung des Altars, Antependien, Velen, Leuchterbank, Stufen, Ciborium und Baldachin, Retabel, Reliquien- und Sakramentsaltar, Altarschranken, München 1924, p. 355; HEMPEL, op. cit., p. 147. See also Donald L. EHRESMANN, „Some Observations on the Role of Liturgy in the Early Winged Altar piece", in: Art Bulletin 64 (1982), 359-369.

${ }^{53}$ KAHSNITZ, op.cit., p. 16.

54 Albert GÜMBEL, Das Mesnerpflichtbuch von St. Sebald in Nürnberg vom Jahre 1482, München 1929; Albert GÜMBEL, Das Mesnerpflichtbuch von St. Lorenz in Nürnberg vom Jahre 1493, München 1928; see also Walter HAAS, „Die mittelalterliche Altaranordnung in der Nürnberger Lorenzkirche”, in: H. BAUER, G. HIRSCHMANN and G. STOLZ (eds.), 500 Jahre Hallenchor St Lorenz zu Nürnberg 1477-1977, Nürnberg 1977, pp. 63-108.

${ }^{55}$ See GÜMBEL, op. cit., pp. 17-18, 30-31.

${ }^{56}$ P. STRIEDER, L. v. WILCKENS (eds.), Germanisches Nationalmuseum Nürnberg. Führer durch die Sammlungen, München 1977, cat. no. 118; Katja von BAUM, Joshua WATERMAN, Meister des Tucher-Altars... in: Datenbank zur
} 


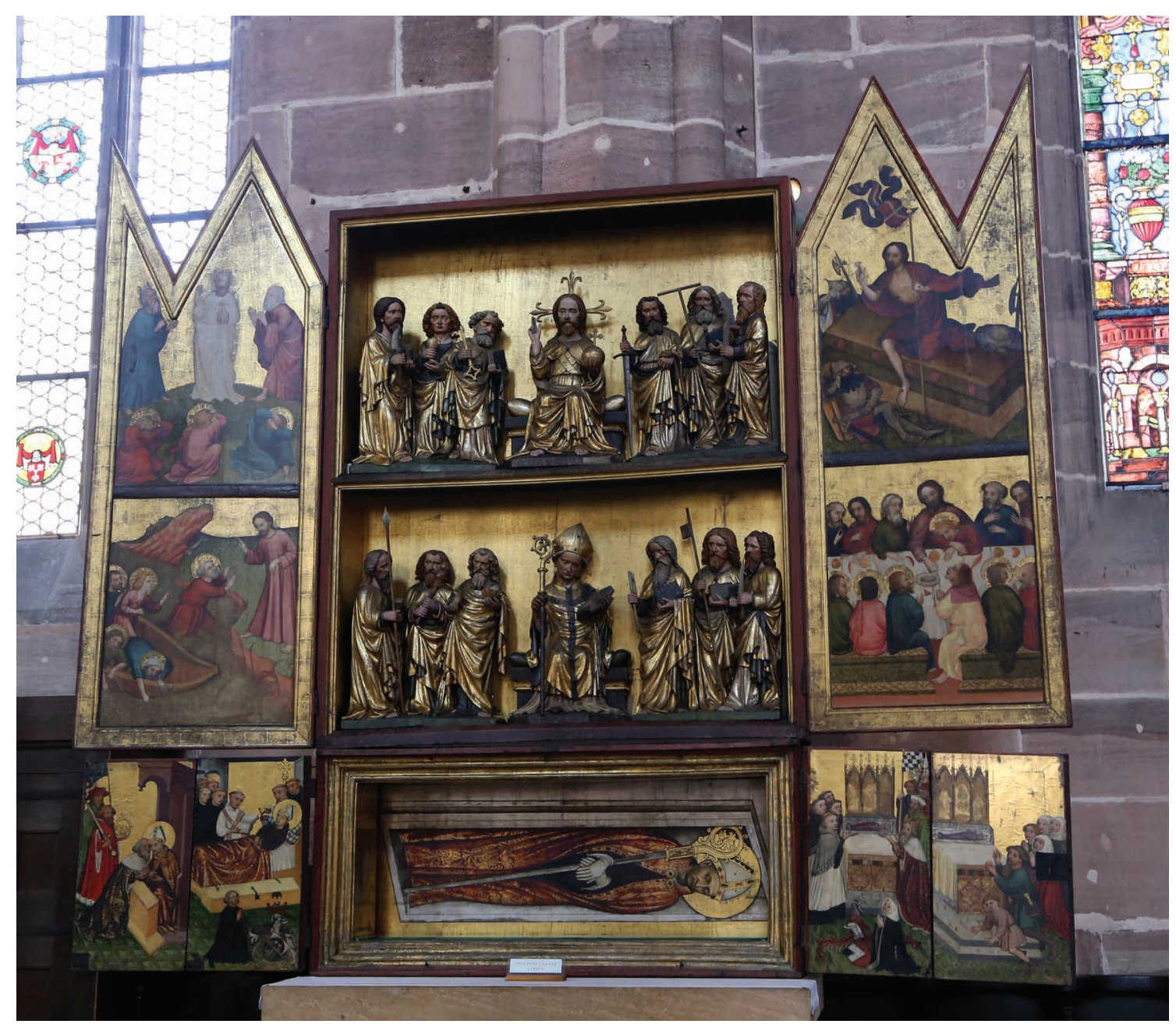

13. Deochar Altar (Deocarusaltar) in St Lawrence Church in Nuremberg, before 1437, fot. Rufus46 https://commons.wikimedia.org/wiki/File:Deocarusaltar_St._Lorenz_Nuernberg-1.jpg

Now let's get back to the question: is it really possible that the panels in York originally formed the predella-wings of the St Catherine of Siena retable? The panels in York indeed seem to have been wings, as they are painted on both sides. They were both painted on a support combined of small pieces of wood, which later cracked and revealed its structure. It almost looks like it was painted on some kind of wooden „left-overs”, so we should rule out the possibility that the panels were initially bigger pieces (e.g. from altar-wings) later cut in the lower part. They indeed seem to have been prepared as the wings of a predella. They were both painted by the same two artists (one depicting the figures on verso and the other one on the recto sides), as their composition is very similar. However, it seems almost impossible to propose a reasonable reconstruction of their original placement in one retable structure.

Most problematic is the fact that one of the panels contains the depiction of the Archangel Gabriel of Annunciation, but there is no Virgin Mary in the other one to complete the

Deutschen Tafelmalerei des Spätmittelalters im Germanischen Nationalmuseum, https://tafelmalerei.gnm.de/objekt/ Gm120 and https://tafelmalerei.gnm.de/objekt/Gm121 (accessed 04.11.2019). The altarpiece was created to the Augustinian Church in Nuremberg by so-called Master of the Tucher Altarpiece; in 1615 it was restored at the expense of the Tucher family and moved to the Our Lady Church in Nuremberg. 

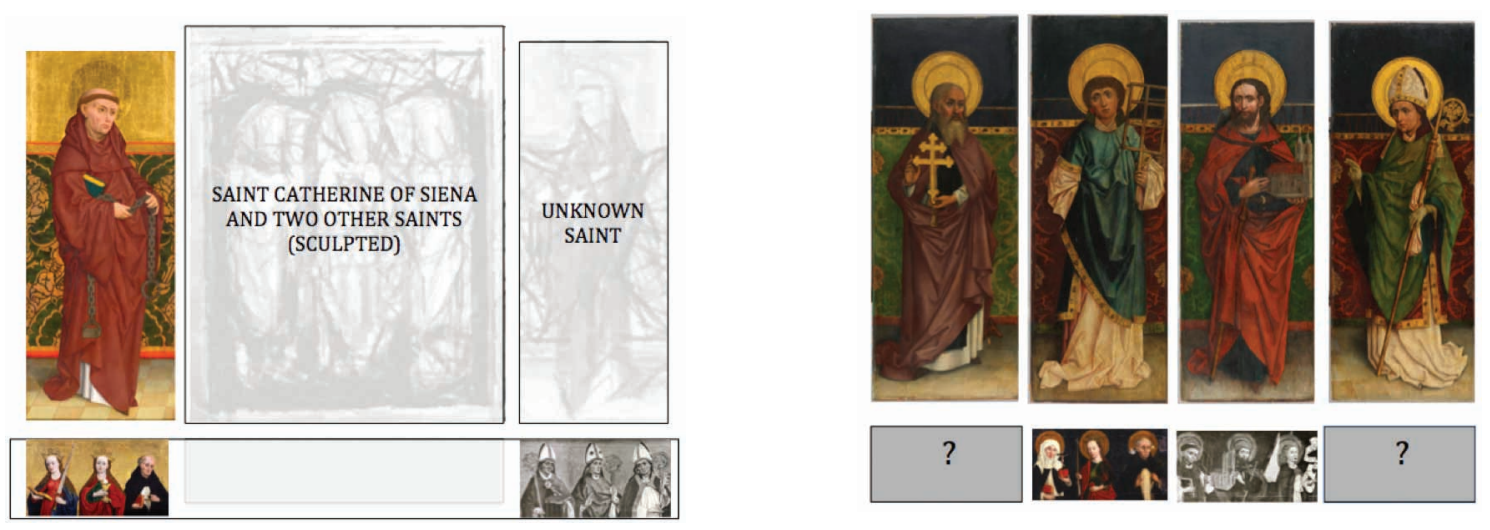

14. St Catherine of Siena altarpiece - unlikely reconstruction including panels from York as predella-wings, by M. Łanuszka.

scene. Robert Suckale suggested that the Virgin was depicted in the central part of the predella (perhaps sculpted) and accompanied by the Angel in the left wing. However, in such case we would have to assume that the dark-background panel was the inner side of a predella wing and the golden-background appeared on an outer side, after the wings were closed, which is highly unlikely. In fact, if we accept the idea that the panels in question were indeed the predella-wings of the St Catherine of Siena altar, there is only one way put them into that structure: the golden-background side would have to match the inner side of the inner wings and the dark background would be a match to the middle opening of the altar. In this case the panel which is still in York must have been the left wing of the predella, and the stolen panel would have been the right wing (otherwise the Angel would be facing St Catherine, which does not make sense). As a result, there would have to be another pair of predella wings, so the predella would be a pentaptych, just as the main structure was. The Virgin Mary of the Annunciation would be in this case depicted in the inner part of the right outer predella wing (fig. 14). It does not seem very probable, and also it should be noticed that in such a reconstruction some saints in the recto side (main opening) are turned outside the central part of predella.

To sum up: such a reconstruction is most likely wrong. First of all, it seems strange not to place the Annunciation scene in the middle part of the whole predella composition. Also, it should be stressed that if the panels were the parts of St Catherine of Siena altarpiece, then the predella would repeat the depictions of the saints already included in the main part (St Sebald, St Lawrence, St Catherine of Siena), which is not impossible, but again - highly unlikely. And finally it does not match the old descriptions of the altarpiece, as there were supposed to have been eight half-length painted figures of the saints (,Am Reliquienschranke sind acht Heilige, Halbfiguren, sehr schön gemaldet"). ${ }^{57}$ If that refered to the opened predella, then the lost middle part would have to contain only two more saints, as six of them are already in the wings. If the descriptions referred to the middle opening of the predella (with the unlikely assumption that it was a pentaptych), then it should have mentioned the Annunciation; and still the outer wings would have to be decorated with only one or two figures. Finally, if it referred to the completely closed predella, then both outer wings would have to contain four saints each (to make it eight together) which seems to be too many for such a panel. The main inner wings of the altar had a width of about $52 \mathrm{~cm}$ and the outer ones about $58 \mathrm{~cm}$ - it is very likely that predella wings

${ }^{57}$ MURR, op. cit., p. 294; see also FRIES, op. cit., p. 116: „Predella: acht Heilige, Halbfiguren”. 

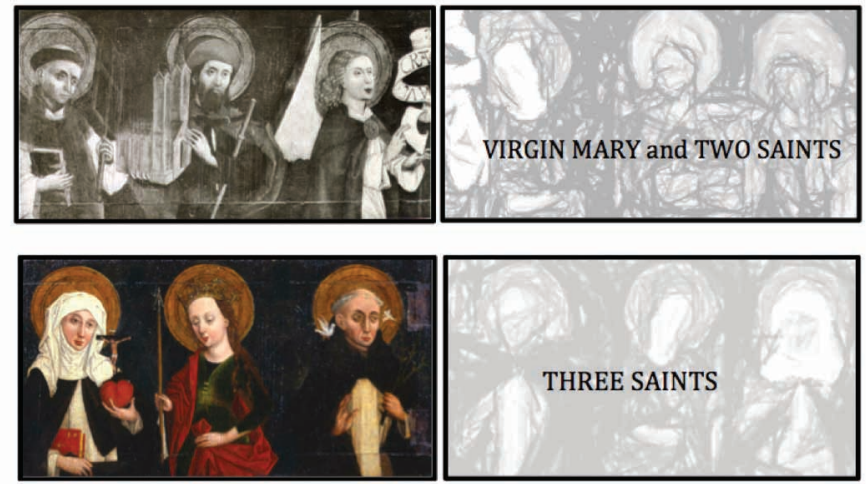

15. Possible reconstruction of the closed predellas

including YORAG $898 a$ and YORAG $898 b$

as left wings of two different predellas, by M. Lanuszka.

matched one of these sizes. In fact, the most probable reconstruction would be either four saints in the central part of the predella and two in each predella wing (so the opened predella would indeed be decorated with eight figures), or perhaps simply eight saints in a predella with no wings at all (which seems most likely judging from the short description). That rules out the St Catherine of Siena altarpiece as the origin of the panels from York.

The next question is: did both York paintings form elements of the same retable? The composition of both is very similar, they were surely painted by the same couple of artists, and the structure of small wood-pieces combined to create the support is the same in both panels. However, if we analyse the panels' compositions a bit closer, we may end up with the conclusion that they were both the left wings of possibly winged predellas. In case of the YORAG 898a it is quite obvious: as its verso side contained the Angel of the Annunciation facing right, it must have been completed with the other panel to the right, depicting Virgin Mary. Both St Lawrence and St Sebald in the York panel were turning towards the Angel, so most likely in the other panel there were two other saints turning left, towards Virgin Mary. The whole composition of the closed predella would as a result contain the Annunciation in its central part and two pairs of saints looking at it on both sides. Meanwhile, the saints on the verso side of YORAG $898 \mathrm{~b}$ are composed in a slightly different way: St Catherine of Siena and St Ursula face each other, while St Thomas is turning right. Again, it seems that this panel should be placed on the left wing and paired with the other one to the right. That missing right panel should include the depictions of another three saints, with the one by the left edge turning towards St Thomas. Most likely in this case the whole composition of the closed predella would contain three pairs of saints facing each other (Fig. 15).

Additionally, it even seems that the panels from York may not have originally been of the same size. If we compare the compositions of the dark-background sides of both panels, we will notice that in the case of YORAG $898 \mathrm{~b}$ all three figures are well-fitted to the cadre, while in the other one the outer figures of St Lawrence and the Angel clearly have been cut on their outer sides. It is possible that the panels now measure the same due to being cut to fit in identical frames, which are most likely not original. The panel still present in York Art Gallery has distinctive hinge marks on the side with the dark background and under the present frame. It is actually quite surprising, as the hinges were usually attached not to the panel itself but to its frame (however predella wings with hinges directly on the panel also sometimes occurred). Even if we assume that it may be one of the cases of hinges placed on the panel without a frame, we would have to accept the panel as intended to be a right wing, which is not likely. In such case St Thomas would be awkwardly composed facing the right edge of the structure and looking beyond the altar. Also, there were no hinge marks on the 
other York panel. As a result, it seems that the panels were reused, possibly in the seventeenth or the eighteenth century (perhaps just like the wings of the altar of St Catherine of Siena) to be the parts of some different, independent structures. One of them was attached to something with the hinges placed directly on the support. Later they were reframed (probably together as a pair) and most likely the golden background was refreshed, as the support is painted in gold together with the frame. The new golden layer must have been thin, as it got cracked, repeating the original craquelures that go through the whole surface, including the figures. That is probably also when the halos around the saints' heads were covered and only the crowns on the female saints' heads have been restored. Still, those crowns in the recto side are now depicted in a much less illusionistic way than the crown in verso depiction of Saint Ursula; perhaps they were repainted on the occasion of regilding and reframing the panel in modern times.

Judging from the selection of the depicted saints, it seems the panel surviving in York Art Gallery used to be part of the altar dedicated to the Dominican church, as it contains the images of three Dominican Saints (Dominic, Catherine of Siena and most likely Thomas Aquinas). That narrows down the probable provenance of the panel to two Nuremberg churches mentioned above: St Catherine's Church (which was the church of the Dominican Nuns' Convent) and the Dominican Church of the male convent. It seems that both churches were decorated with the altars completed by the same workshops, which is not surprising. The wings of the St Catherine of Siena Altar of St Catherine's Church were created in the workshop of Hans Pleydenwurff; a similar composition (full length depictions of the saints, golden background with the painted cloth) was used by same workshop in the altar of the Three Magi (Three Kings) for the Dominican Church (ca. 1470, the wings are now in the Germanisches Nationalmuseum in Nuremberg, GM129 and GM130). ${ }^{58}$ Also sculpted parts of the altarpieces in both churches were in some cases completed by the same workshops: for example the altar from St Catherine's Church containing a sculpted Crucifixion with St Catherine, St John the Baptist and two Dominican Saints ${ }^{59}$ was created probably in the 1450 s by the same workshop as the Crucifixion Altar from the southern aisle of the Dominican Church. ${ }^{60}$ Unfortunately the existing eighteenth century descriptions of the altars rarely refer to their predellas, and we should remember that both Dominican convents in Nuremberg were closed in the sixteenth century, so some of the altars may have been demolished or removed at that time.

To sum up: it seems that the panels from York used to be the left wings of retable predellas. The panel that was stolen from York was probably originally paired with a similar one with the depiction of the Virgin completing the Annunciation scene on the verso side, most likely placed in the middle part of the predella when the wings were closed. The panel still in York may have been a part of a second pair of predella-wings, perhaps even from some other retable created by the same artists. In any case, both York panels were for sure created around the same time and by the same workshop. It seems that it was the

\footnotetext{
${ }^{58}$ See Stefan ROLLER, Gerhard WEILANDT, „Der Dreikönigsaltar in St. Lorenz und Hans Pleydenwurff”, in: Ch. SCHMIDT, G. STOLZ (eds.), Hundert Jahre Verein zur Erhaltung der St. Lorenzkirche 1903-2003. Sammelband der Referate des Kolloquiums aus Anlass des Vereinsjubiläums, (Schriftenreihe des Vereins zur Erhaltung der St. Lorenzkirche in Nürnberg e.V. 2), Nürnberg 2004, pp. 35-44; SUCKALE, Die Erneuerung..., vol. 1, pp. 134-138; vol. 2, cat. no. 41.

${ }^{59}$ Frank Matthias KAMMEL, „Spätmittelalter”, in: Germanisches Nationalmuseum. Führer durch die Sammlung, Nürnberg 2012, p. 70.

${ }^{60}$ Friedrich BOCK, ,Das Nürnberger Predigerkloster - Beiträge zu seiner Geschichte”, in: Mitteilungen des Vereins für die Geschichte der Stadt Nürnberg 25 (1924), p. 197.
} 
workshop of Hans Pleydenwurff, and as the recto sides of the York panels were painted by the same painter who worked on the wings of St Catherine of Siena altarpiece (which dates back to 1464), it is reasonable to assume that they were also created in the 1460s. They come from a Nurembergian church and it is very likely that it was either St Catherine's Church or the Dominican Church. They should not be, however, considered as the parts of predella of the St Catherine of Siena retable, as it seems impossible to fit them into the reconstruction that would be iconographically reasonable and suiting the eighteenth century descriptions. Hopefully the panel stolen from York in 1979 will be recovered one day, and perhaps the others will show up (e.g. the one with the Virgin to complete Annunciation scene), which would enable further examination that could lead to more detailed conclusions. 


\section{Późnogotyckie tablice z kolekcji York Art Gallery- skrzydła predelli z warsztatu Hansa Pleydenwurffa}

Artykuł przedstawia wyniki badań przeprowadzonych w ramach projektu National Inventory of Continental European Paintings. Omówione w nim dwie późnogotyckie tablice należą do zbiorów York Art Gallery i zostały podarowane w 1957 r. przez F.D. Lycett Greena, który zakupił je w Arcade Gallery w Londynie. Niestety obecnie w kolekcji York Art Gallery znajduje się tylko jedna z tych tablic (nr 898b), gdyż druga (nr 898a) została skradziona 13 XI 1979 r.

Obie tablice mają wymiary $25 \times 49.1 \mathrm{~cm}$, są obustronnie malowane na podobraziu $\mathrm{z}$ sosnowych desek. Najprawdopodobniej stanowiły skrzydła predelli ołtarza szafiastego. Obie zawierają po trzy przedstawienia świętych w półfigurach na każdej ze stron $-\mathrm{z}$ jednej strony na złotym tle, $\mathrm{z}$ drugiej na tle ciemnym. Skradziona tablica $\mathrm{nr} 898 \mathrm{a}$ na stronie recto (ze złotym tłem) zawierała wizerunki świętych biskupów: Mikołaja, Serwacego i - prawdopodobnie - Augustyna, a na stronie verso świętych Wawrzyńca i Sebalda oraz Archanioła Gabriela z banderola z napisem AVE GRA[tia], niewatpliwie stanowiącym fragment sceny Zwiastowania - wszystkie postacie są zwracają się w prawą stronę. Tablica nr 898b zawiera na stronie recto wizerunki świętych dziewic: Katarzyny i Barbary oraz świętego dominikanina (zapewne św. Dominika). Na stronie verso ukazane zostały zwrócone ku sobie św. Katarzyna ze Sieny i św. Urszula oraz dominikanin, zapewne św. Tomasz z Akwinu, zwrócony w prawo. Prawy brzeg tablicy nosi ślady po zawiasach pod obecną ramą. Śladów takich nie było na tablicy 898a.

Jeden artysta malował postacie na stronie verso obu skrzydeł, inny zaś stworzył przedstawienia na stronach recto. Ten ostatni niewątpliwie może być utożsamiany z twórcą skrzydeł z ołtarza św. Katarzyny Sieneńskiej, który został ukończony w 1464 r. w warsztacie Hansa Pleydenwurffa dla kościoła dominikanek pw. św. Katarzny w Norymberdze. Ołtarz ten nie zachował się w całości; jego wygląd znany jest z krótkich opisów z XVIII w. - był to pentaptyk, zawierający w predelli półfigurowe przedstawienia ośmiu świętych. Cztery tablice ze skrzydeł tej nastawy znajdują się dziś w zbiorach Germanisches Nationalmuseum w Norymberdze, jedna zaś w North Carolina Museum of Art w Raleigh NC w USA.
Niewątpliwie obie tablice $\mathrm{z}$ kolekcji York Art Gallery powstały w warsztacie Hansa Pleydenwurffa, zapewne dla któregoś z norymberskich kościołów dominikańskich. Wydaje się, że można datować je na lata 60. XV w., ponieważ wykazują bardzo wyraźne stylistyczne związki ze wspomnianymi wyżej skrzydłami norymberskiego ołtarza św. Katarzyny z roku 1464. Jednakże wbrew dotychczasowym sugestiom badaczy, tablic z Yorku nie można uznać za skrzydła predelli tego właśnie ołtarza. Nie pasują one do zachowanych opisów nastawy, a w dodatku nie da się zestawić ich tak, aby tworzyły sensowną kompozycyjnie całość. Wydaje się nawet, wbrew dotychczasowym założeniom, że dwie tablice z York Art Gallery, choć niewątpliwie namalowane przez tę samą parę artystów, nie stanowiły pierwotnie pary skrzydeł jednego ołtarza; najprawdopodobniej są to dwa lewe skrzydła. Zapewne pierwotnie nie były również tych samych rozmiarów - prawdopodobnie wyrównano ich proporcje i oprawiono w identyczne ramy, aby sprzedać je jako parę w XIX lub XX w. Postacie na stronie verso skradzionej tablicy 898a zostały bowiem przycięte po bokach, podczas gdy postacie na tablicy 898b idealnie mieszczą się w kadrze.

Sądzę, że skradzione skrzydło 898a było zestawione $\mathrm{z}$ innym, być może zawierającym na stronie recto przedstawienia innych trzech biskupów, na stronie verso zaś z pewnością musiała znajdować się postać Matki Boskiej, dopełniająca scenę Zwiastowania, oraz dwójka świętych, prawdopodobnie zwróconych w lewo. W takim przypadku skrzydło 898 b zestawione byłoby z jakimś innym, w którym postacie świętych na stronie verso powinny były być zwrócone ku sobie nawzajem.

Niestety oba dominikańskie kościoły w Norymberdze (przy męskim i przy żeńskim klasztorze) zostały przejęte przez luteranów w czasach Reformacji; dawny kościół dominikanek (św. Katarzyny) w 1945 r. uległ zniszczeniu (do dziś pozostały jedynie ruiny), a były kościół dominikanów (pierwotnie pod wezwaniem maryjnym) rozebrano w początkach XIX w. Pochodzące z XVIII stulecia opisy wyposażenia tych kościołów nie pozwalają stwierdzić, do jakich dokładnie ołtarzy mogły należeć omawiane w niniejszym artykule skrzydła predelli. 